\title{
Utak és irányok a Székely Nemzeti Múzeum életében
}

VARGHA MIHÁLY

sepsiszentgyörgyi Székely Nemzeti Múzeum 20I5-ben I40 éves, ma a
magyar nyelvterület egyik jelentős közgyújteménye és tudományos-
múvelődési intézménye. Története során megért többszöri székházcse-
rét, impérium- és rendszerváltást, tragikus sorsú menekítést, államosítást,
de világkiállításon való részvétellel, nemzetközi elismertséggel és komoly
gyarapodással is büszkélkedhet.

A Székely Nemzeti Múzeumot I875-ben alapította Imecsfalván özv. Cserey Jánosné Zathureczky Emília. Társa az alapításban az első múzeumőr, Vasady Nagy Gyula volt. A múzeum I882-1952 között, alapítólevelének megfelelően, saját neve alatt múködött, és alapszabályai szerint gyújteménye a székely nép elidegeníthetetlen tulajdona.

I924-ben, alapítványként jogi személynek ismerte el a román állam is, ezt még 1946-ban is megerősítette. 1949-52 között államosították, ezután különböző közigazgatási egységek állami tulajdonaként kezelték a múzeumot. 1969 óta Kovászna Megyei Múzeum a gyúijteményeink státusa, ilyen minőségben hozták létre már akkor a kézdivásárhelyi, kisbaconi, később más kiállítóhelyeket, bővítették 1972-73-ban kézdivásárhelyi és csernátoni részleggel.

Az 1970-80-as években zajlott az eredeti tervek szerinti épületbővítés, új részlegeket alapítottak (kézdivásárhelyi, csernátoni, kisbaconi; Sepsiszentgyörgyi Képtár), Csernátonban kiteljesedett a skanzen, Baász Imre megszervezte a később nemzetközivé bővülő Medium kortárs kísérleti képzőmúvvészeti seregszemlét, és a múzeum Aluta címú évkönyve a legnagyobb kisebbségi magyar szakperiodikának számított.

Új korszak kezdődött az 1990-es években, ennek jellemzői: a múzeum eredeti jellege igényelte alapkiállitások visszaállítása; visszaintegrálódás 
a magyar (a feljavított épületú képtár esetében a nemzetközi) múvészetikulturális, tudományos intézményrendszerbe; a részlegek autonómiájaönállósulása.

A Székely Nemzeti Múzeum regionális intézmény, fenntartója a Kovászna Megye Tanácsa. Könyvtári, természetrajzi, régészeti-történelmi és néprajzi osztállyal múködik, valamint sepsiszentgyörgyi képzőmúvészeti (Gyárfás Jenő Képtár, Magma Kiállítótér), baróti (Erdővidék Múzeuma), csernátoni (Haszmann Pál Múzeum), kézdivásárhelyi (Céhtörténeti Múzeum) és zabolai (Csángó Néprajzi Múzeum) külső egységekkel.

\section{Belső múzeumi osztályok}

\section{KÖNYVTÁR}

Osztályunk egyrészt az intézmény tudományos munkáját segítő szakkönyvtárat múködteti, másrészt számottevő régikönyv-, sajtó- és egyéb különleges gyúijteménnyel rendelkezik. Legkiemelkedőbb értéke az itt őrzött Apor-kódex, amelybe I50o körül többek között az első magyar bibliafordítás (I5. század) zsoltárait másolták. (Az említett bibliafordítás a fennmaradt negyedik legrégibb magyar irodalmi múnek tekinthető.)

\section{TERMÉSZETTUDOMÁNYI OSZTÁLY}

Kelet-Közép-Európa egyik legteljesebb pliocén- és negyedkori emlősfauna-kollekciója mellett a legnagyobb romániai nagygombagyújtemény, a több mint 23 ooo példányt számláló Diószeghy László-féle lepkegyưijtemény, valamint egy igen jelentős botanikai kollekció található itt. Rovartanos szakemberének nevéhez több új faj felfedezése kapcsolódik.

\section{RÉGÉSZETI-TÖRTÉNELMI OSZTÁLY}

Régészeti gyújteményanyaga 50 ooo tételnyi. A múzeum kiemelten a Kovászna megyei Erősd újkőkori-rézkori festett kerámiás kultúráját, a lécfalvi újkőkori lelőhely anyagát, a zabolai és petőfalvi Árpád-kori temetők leleteit kutatta és rendszerezte. A régészeti alapkiállítás a térség 35000 évnyi tárgyi kultúráját mutatja be a látogatóknak.

A történelmi gyưiteményből másfelől a székely rendek középkori katonáskodásának az emlékanyaga, az I848-as relikviák (pl. Bem tábori nyomdája), a több mint 250 darabos fegyvergyújtemény, valamint a jelentős múvelődéstörténeti értékú bútor- és üvegkollekció kiemelendó érték. 

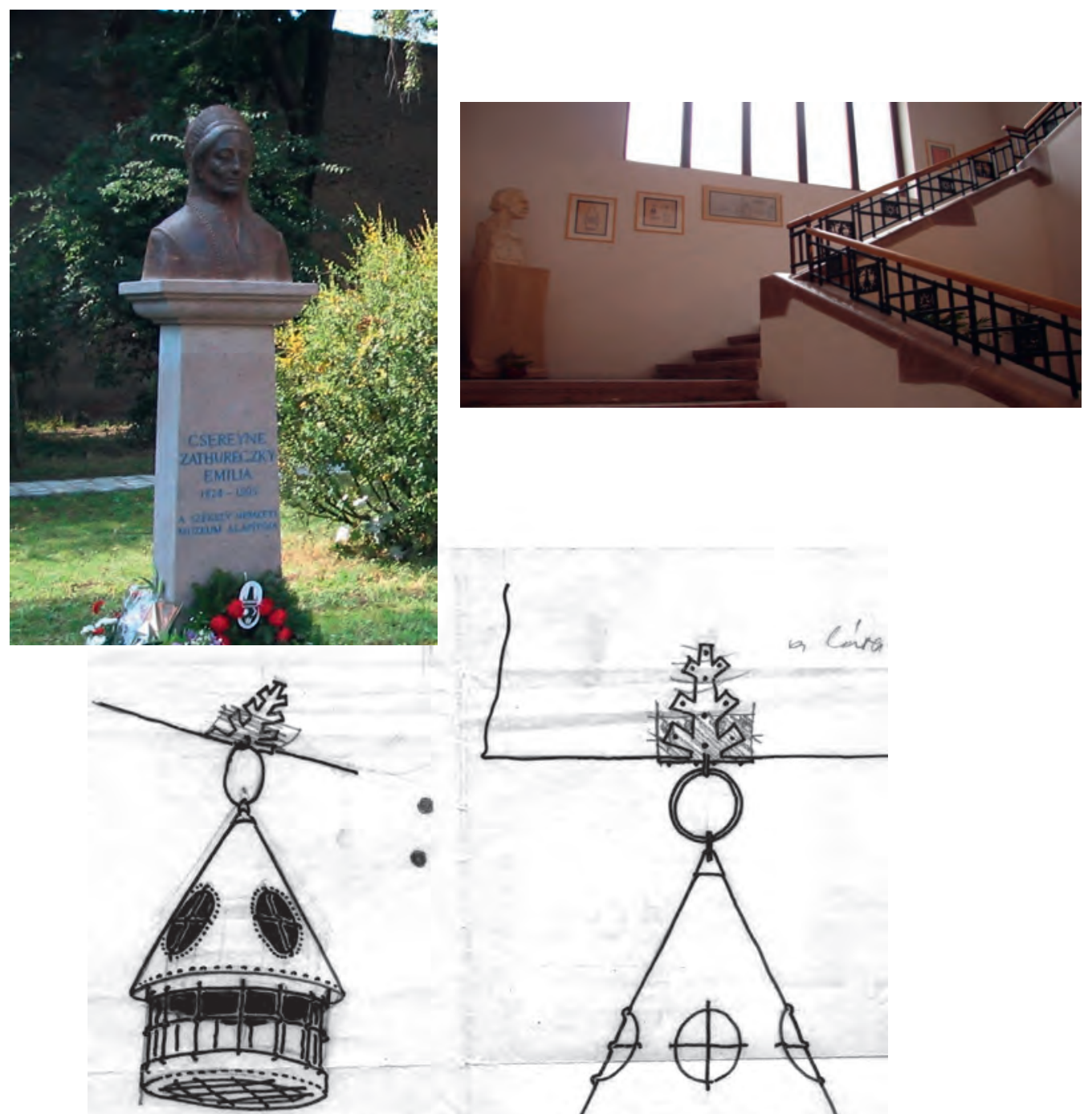

Arriscrashuealó'e kinitendó

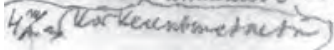

KOVACSOLT-VAS-LÁMPA'S. A.BELARATI. KAPU-TOROMYHOZ: A.MESTERGEREMDA'RA FÜGGESTTVE.

GGEPTEK: $1: 5$

betainge-ain. 2\% Libaing
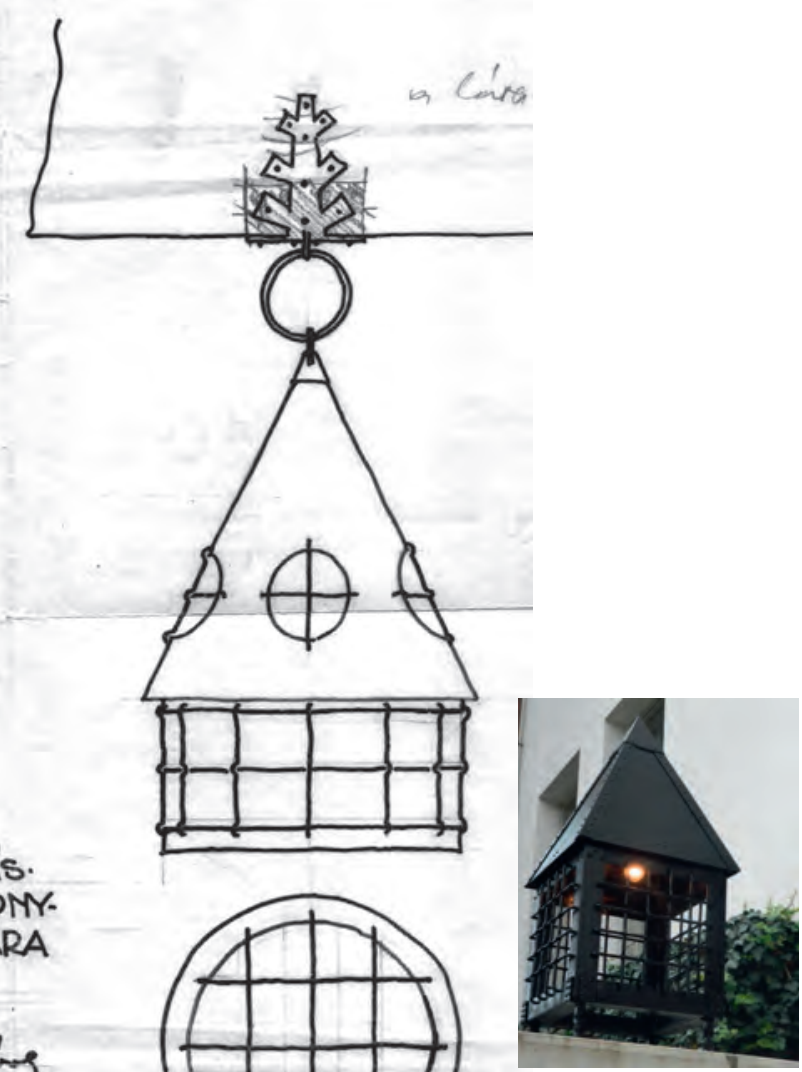


\section{NÉPRAJZI OSZTÁLY}

Több mint 15 ooo darabot számláló állományából a I7-I8. századi úri hímzések Erdélyben egyedülállóan gazdag gyújteménye, a jelentős kályhacsempe- és kerámiakollekció, faragott és festett régi bútorok, valamint a hagyományos népi gyermekjátékok rendkívüli kollekciója emelhető ki. Szabadtéri kiállításunkban másrészt I8. századi, részben eredeti berendezésú alcsíki ház tekinthető meg.

\section{Külső egységek}

A Székely Nemzeti Múzeum Kovászna megyei szervezetéhez tartozik további öt autonóm, szakosodott múzeumi intézmény.

\section{GYÁRFÁS JENŐ KÉPTÁR, SEPSISZENTGYÖRGY}

A sepsiszentoyöroyi Gyárfás Jenő Képtár I9-20. századi festészeti, szobrászati, grafikai alkotásoknak biztosít szakszerú raktározási és kiállítási felületet. Mindenekelőtt Barabás Miklós, Gyárfás Jenő, Zsögödi Nagy Imre, a nagybányai festőkolónia múvészei, Varga Nándor Lajos és mások múveiben gyönyörködhetünk.

\section{INCZE LÁSZLÓ CÉHTÖRTÉNETI MÚZEUM, KÉZDIVÁSÁRHELY}

Rangos város- és céhtörténeti, kézmúvesség- és ipartörténeti gyúitemény és kiállítás. A céhes örökség és az I848-49-es emlékanyag mellett látványos a múzeum 19-20. századi túzoltókocsikat felvonultató gyúiteménye. A legismertebb kollekció az itt kiállított, mintegy 350 darabos „Zsuzsi és Andris” babaméretú viseletgyújtemény. A múzeum szakembereit dicséri a neves Bogdán fényképészcsalád napfénymúterme is, amely ma már fotográfiatörténeti kiállítóhely.

\section{HASZMANN PÁL MÚZEUM, CSERNÁTON}

Kovászna megye népi építészeti örökségét, hagyományos foglalkozások tárgyi eszközeit, sírjeleket bemutató szabadtéri kiállítás, kiemelkedő néprajzi és történeti mútárgykollekcióval. Hírét az egyedülálló mezőgazdasági gépparknak és technikatörténeti gyúiteménynek, a látványos öntöttvaskályha-kollekciónak s nem utolsósorban a népfőiskola keretében múködtetett népmúvészeti alkotótáboroknak köszönheti. 


\section{ERDÓVIDÉK MÚZEUMA, BARÓT}

Bányászattörténeti és céhes emlékek, ipar- és helytörténeti tárgyak kollekciója és kiállítása. Kiemelkedő értékú a székelyföldi üveghuták, valamint az erdővidéki fazekasok termékeinek gyújteménye.

\section{CSÁNGÓ NÉPRAJZI MÚZEUM, ZABOLA}

Egyedülálló gyưjitemény és megragadó kiállítás a moldvai magyarok népmúvészetéből és mindennapi életéből. A hagyományos moldvai magyar életutak viseleteken, kézmúves termékeken és falvaik szobabelsőin követhetők nyomon. Az ugyanezen telken berendezett régi székely házban rendkívül gazdag helytörténeti gyújtemény is megtekinthető.

Bevételeink a látogatói belépési díjból, terembérbeadásból, régészeti felügyeleti díjakból tevődnek össze, és a programokra költött összegnek valamivel több, mint egynegyedét jelentik. Forrásbiztosító munkánkat a Székely Nemzeti Múzeum Alapítvány továbbra is hatékonyan segíti.

A Székely Nemzeti Múzeumban az utóbbi tíz évben egy megújulási folyamat kezdődött. Igyekeztünk javítani a közönségszolgálaton, a programajánlaton, de a tudományos kutatás és a periodikák, szakkönyvek kiadásának minőségén is. Igyekeztünk gondoskodni a hozzánk tartozó külső egységek: Csernáton, Kézdivásárhely, Zabola, Barót felzárkóztatásáról is.

Szerteágazó tevékenységünket az alábbiak során részletesen taglaljuk.

A Kós Károly által I9I2-ben megálmodott kovácsoltvas korlát és a múzeumi mozaikcímer felavatására került sor 2008. szeptember 20-2I-én a Kulturális Örökség Napok címú kétnapos nemzetközi rendezvény alkalmából.

„Kós Károly ars poeticájában kihangsúlyozott elem, hogy helyi anyagokból kell építkezni, helyi mesterekkel kell dolgoztatni. A mestereitől ő is kőkeményen megkövetelte a minőséget, de az eredmény őt igazolja: a Székely Nemzeti Múzeum ugyanis az egyetlen Erdélyben, ami múzeumnak épült, amely a székely és az erdélyi kultúra fellegvára, és mai napig töretlenül akként is múködik. Ehhez szerettünk volna ezzel a korláttal is hozzájárulni” - hangzott el a megnyitóbeszédben.

A sepsiszentgyörgyi múzeum 20I2. szeptember 19-én százéves épületegyüttesét ünnepelte. Kós Károly Székely Nemzeti Múzeumával, a közösségszervező múvész talán legszebb, reprezentatív alkotásával I9I2 óta büszkélkedhet a város és az erdélyi magyarság. I9I2 őszén nem alaptalanul fordult a múzeum vezetôsége Sepsiszentgyörgy városához állandó, a múködését biztosító támogatásért. A száz éve saját székházat kapó intézmény akkori és mai életében hasonlóság az önkormányzatok feltétlen erkölcsi és anyagi támogatása.

I3O VARGHA MIHÁLY 

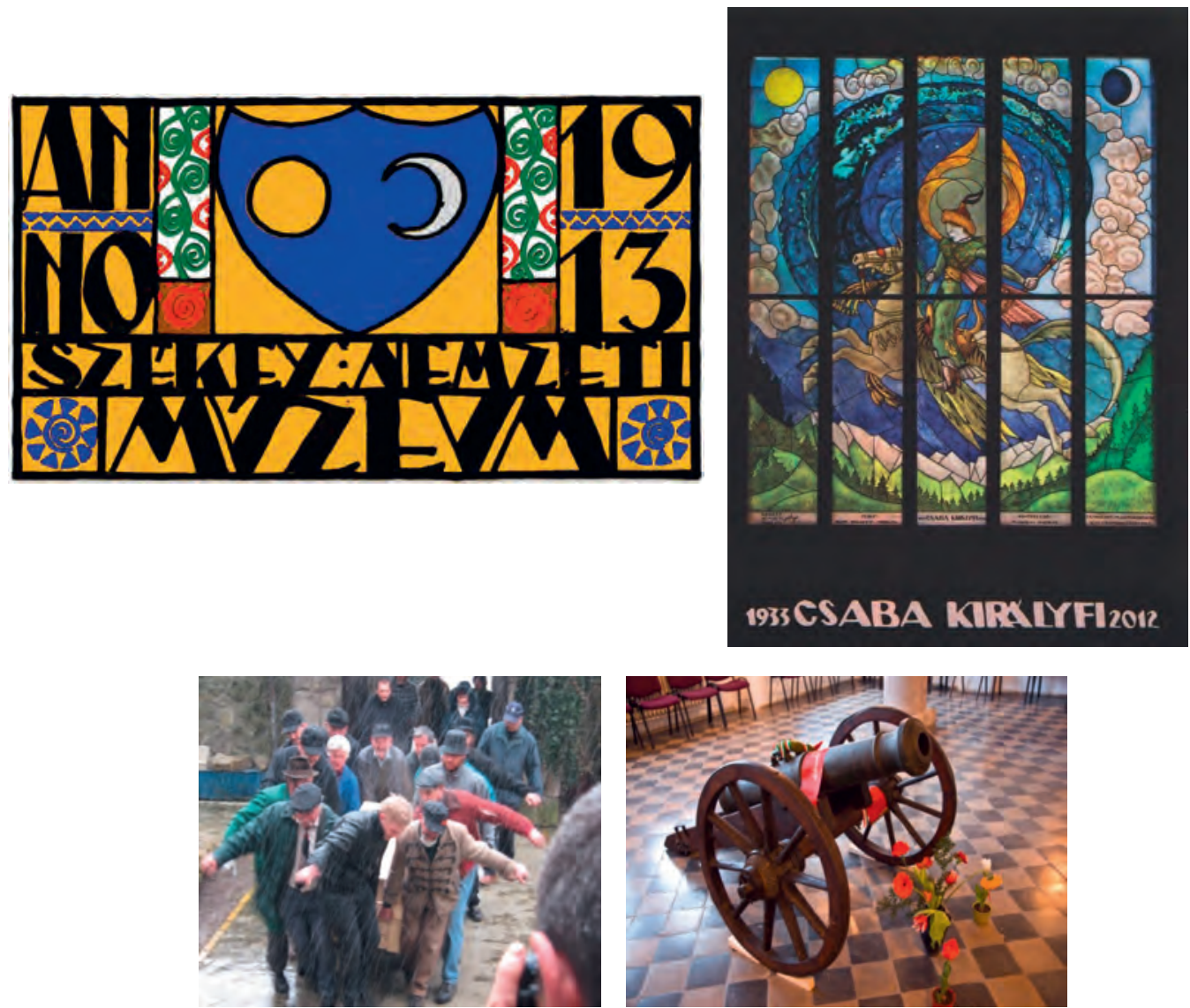

A centenáriumi ünnepség alkalmával avatta a múzeum a Kós Károly által még I9I4-ben megtervezett kovácsoltvas lámpásait, az olaszteleki vasmúves Nagy György kivitelezésében, és bemutatásra került a múzeumépületeket ismertető színes könyvecske.

20I2-ben csodálatos üvegfestménnyel gazdagodott a Székely Nemzeti Múzeum.

A Székely Nemzeti Múzeumban hat éve kezdődött az a program, amelynek keretében a vázlatrajzokban fennmaradt épületdíszítések kivitelezését tûzztük ki célul. E program keretében készült el a kovácsoltvas korlát és lámpa, a múzeumcímer, a díszterem padjai.

A Csaba királyfi üvegfestmény mintegy megkoronázza ezt a sorozatot. Úgy idézi meg a székely eredetmítoszt, hogy közben kellemes, templombelsőre emlékeztető fényhatást kölcsönöz a lépcsőháznak.

A kézdivásárhelyi ágyúlelet - mai ismereteink szerint az egyetlen megmaradt, az I849-es kézdivásárhelyi gyárban öntött ágyúcső - I906. augusztus I8-án került elő az óváros területén, az egykori Rudolf Kórház udvarán 
végzett földmunkák alkalmával. 1923-ban az ágyú a Székely Nemzeti Múzeumban nyert elhelyezést, majd I97I-ben felsőbb utasításra, múzeumunk több más értékes múkincsével együtt Bukarestbe, a frissen létrehozott országos román történeti múzeum (Muzeul Național de Istorie a României) gyújiteményébe került.

Bukarestből az ágyú 20IO-ben Sepsiszentgyörgyre érkezett, ahol a március I2-én megnyíló In Memoriam Gábor Áron (I8I4-1849) tárlat keretében lehetett megtekinteni. A 2,5 milliárd régi lej értékú történelmi kincset nemcsak pár hétig lehetett megtekinteni, hanem végleg visszakerült jogos helyére, a Székely Nemzeti Múzeumhoz.

\section{Az infrastruktúra fejlesztése}

A múzeumunk fejlesztését szolgáló, egyedülálló, sőt történelminek is nevezhető esélyt sikeresen használtuk ki, és fenntartónk támogatásával megvásároltuk a szomszédságunkban fekvo 40 áras telket, ahová az elkövetkező öt évben egy mútárgyvédelmi és egy adminisztratív központ megépítésére és üzembe helyezésére is esély mutatkozik.

A tervezésre a Kós-dijas Zakariás Attila múépítészt kértük fel. Készülnek a tervek, a véleményezések, a fenntartó Kovászna Megye Tanácsa támogat a törekvéseinkben. A legfontosabb azonban, hogy ezáltal komoly lehetőségünk nyílik az évtizedek óta tartó kínzó raktárgondjainknak a megoldására.

Pozitív fejlemény továbbá, hogy az új uniós támogatási kiírásban újra megpályázzuk a százéves, Kós Károly tervezte múzeumépület teljes rehabilitációját és korszerúsítését, amely nélkül évtizedekig tarthat a megújulási folyamat.

Nagy szükseg van a víz-, villany- és gázvezetékek kicserélésére, korszerúsítésére, a tetőzet javítására is, de arra is, hogy logikusabb beosztást nyerjenek a belső terek, látogatóbarátabbá váljon a múzeumunk, növekedjék a kiállítófelület.

Ez a tervünk nemcsak intézményünk, hanem városunk és régiónk idegenforgalmának fejlesztését is elősegitheti.

\section{Állagmegőrzés és restaurálás}

Kiemeltebb szakmai terveinket is megvalósíthattuk: az Apor-kódex mellett restauráltattuk a zabolai szárnyas oltárt, múemlék székely kapuinkat kon- 
zerváltuk, és ha a szükség úgy hozta, szakembereink az intézmény falain kívül is fontos szolgálatot teljesítettek, elöljáróban csak egy-két példa: a Székelykapu-program keretében kaput mentettünk be Futásfalváról.

- Az Apor-kódex restaurálását a Romániai Országos Könyvtárral való partnerség tette lehetővé, és az Országos Széchényi Könyvtár Restauráló és Kötészeti Osztálya végezte el Érdi Marianne osztályvezető, valamint Tóth Zsuzsanna restaurátor közremúködésével.

- 20I4-ben megjelent az Apor-kódex új kiadása, mely a SzNM A. I33O. jelzetú kódexéról készült. A kiadás a sepsiszentgyörgyi Székely Nemzeti Múzeum, az Országos Széchényi Könyvtár és az ELTE Magyar Nyelvtudományi és Finnugor Intézetének együttmúködésével valósult meg. A kiadványt a kódex digitalizált változata kíséri DVD formájában. A kötet adatai: Apor-kódex. I5. század első fele, I5. század vége és 1520 előtt. A nyelvemlék hasonmása és betủhú átirata bevezetéssel és jegyzetekkel.

- A Könyvtár számára Budapest Fơváros Levéltára szakemberei restaurálták múzeumépületeink Kós-tervrajzait.

- A Régészet-Történelmi Osztály munkatársai egyrészt a régészeti gyúijtemények revíziójával, a régészeti adattár rendszerezésével, az elmúlt évek ásatási (Erősd, Kisborosnyó, Sepsiszentgyörgy) leletanyagának leltározásával (eddig 4500 tárgy) foglalkoztak; illetve befejezték a történelmi gyújtemény pecsétnyomóinak (249 db) a rendezését, adatlapjaik kiegészítését, s dolgoznak a numizmatikai gyújtemény (érmék, bankjegyek) és a történelmi fegyvertár rendszerezésén, a tárolási körülmények optimalizálásán, valamint elkezdték a textíliák (miseruhák, szőnyegek) osztályozását és restaurálását.

- A Székelykapu-program keretében új ráklábakra helyeztük a területünkön álló öt székely kaput. A munkálatok szakfelügyelője Domokos Levente székelykeresztúri restaurátor, a munkálatokat koordináló vállalkozó Zsók József volt. A ráklábcsere modern konzerválási alapelvek szerint történik: hántással, égetéssel, bórpasztillás, biokomplexes, wolmanolos kezeléssel biztosítjuk a kapuk hosszú távú megőrzését.

- Szőcsné Gazda Enikő felügyelete alá került az intézmény fototékája. A nyilvántartási rendszer digitalizálása és a képek rendszerezése jelentősen meggyorsította a kutatók kiszolgálását.

- A Gyárfás Képtár gyúijteményébe rongált állapotba került, báró Szentkereszty Stefániát ábrázoló olajfestményt Vinczeffy László restaurálta. 
- A Haszmann Pál Múzeum munkatársai a szokott rendszerességgel kezelték korrózió elleni szerekkel a szabadtéri múzeum fa- és fémtárgyait.

- A Csángó Néprajzi Múzeum gyúijteményéből textíliákat restauráltunk, illetve több öntöttvas kályhát konzerváltunk szakszerúen.

- A I7. századi Pieta-szárnyasoltár (Ltsz: I4I55) restaurálása 20II-ben történt meg. A szárnyasoltár állagmegóvása és helyreállitása során a következő munkafolyamatokat végeztük el:

- kutatás, vizsgálatok, restaurálási terv készítése;

- az oltár szétbontása és múterembe való szállítása;

- a faanyag biológiai kártevők elleni fertőtlenítése;

- a festett és festetlen felületek tisztítása, feltárása;

- a festékréteg konzerválása.

- I7. századi úri hímzést restauráltatott a Székely Nemzeti Múzeum. A hímzés - a restaurálási folyamatok ismertetésével együtt - 2012. november 20-tól múzeumunkban kiállításra kerül. A budapesti Nemzeti Kulturális Alap támogatásával a múzeumnak az egyik leghíresebb úri hímzését sikerült restauráltatnia a szebeni Brukenthal Nemzeti Múzeum restaurátorlaboratóriumában Simona Stănculescuval, a romániai restaurátorkamara régi hímzésekre szakosodott szakértőjével.

- Fơépületünkben a kritikus állapotban lévő déli szárny födémének és tetőszerkezetének teljes felújítását is elvégeztük.

- Felújítottuk a déli oldalon fekvő múzeumőri lakás tetőszerkezetét és lépcsőjét.

- A múzeumépület ıoo. születésnapjára a lépcsőházban felavattuk a gróf Bánffy Miklós által tervezett monumentális Csaba királyfi vitráliumot.

- A centenáriumi ünnepségek keretében helyi kovácsmesterrel kiviteleztettük a Kós Károly által tervezett bejárati két állólámpát és a „szakállszárító” bejáratának függőlámpáját;

- 2012. szeptember-novemberben az Incze László Céhtörténeti Múzeum fóépületének tetőszerkezeti felújítására és javítására, majd 2013. június és július között az épület fŏtér felőli frontjának javítására került sor.

- 2013 őszén sor került a fóépület Tolerancia- és Lovagterme teljes felújítására, világítástechnikájának a korszerúsítésére. 

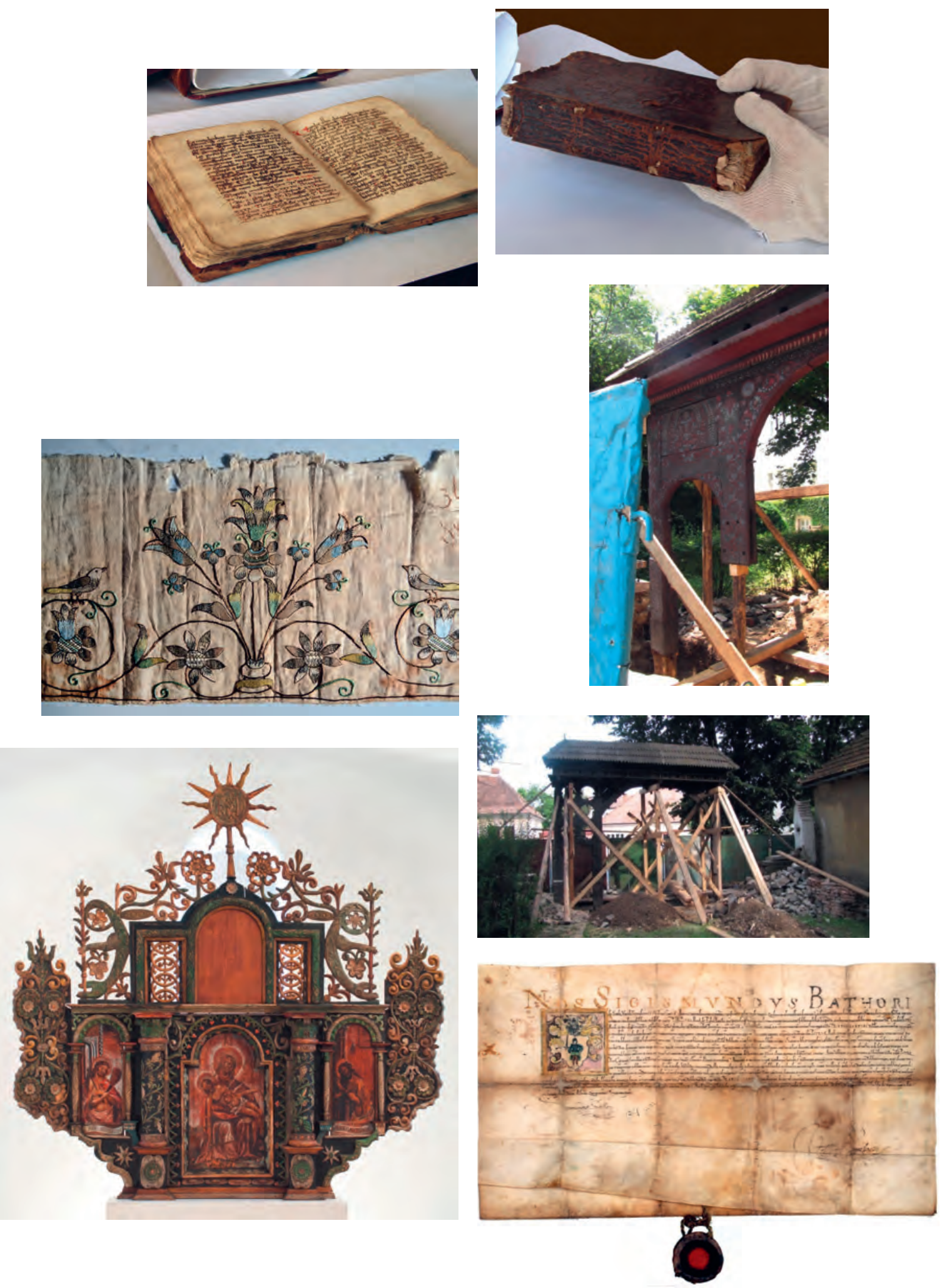

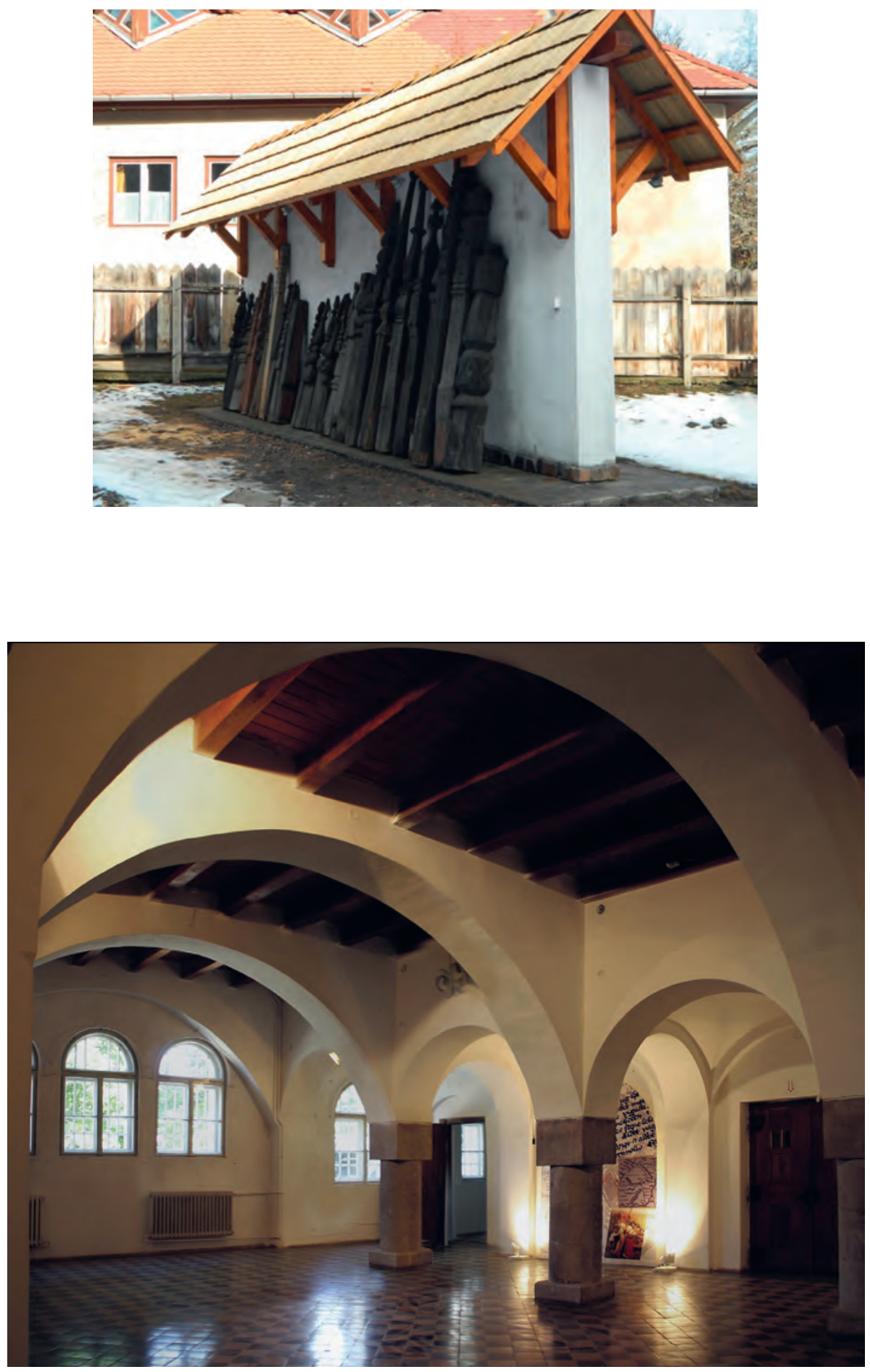

I36 VARGHA MIHÁLY 
Teljesen új tetőszerkezetet kapott az intézmény szabadtéri részlegéhez tartozó egyetlen tájház, a I8. századi csíki ház is, amely mellé egy kopjafatároló is elkészült.

\section{Gyưijteménygyarapítás}

A sepsiszentgyöroyi székhely és a külső egységek gyújteményei a tárgyalt időszakban ezres nagyságrendú tárgyi gyarapodást értek el, emellett jelentôs dokumentumanyag (fényképek, iratok) és számos könyvtári kiadvány bővítette állományunkat.

- Négyszáz éves nemesi oklevelet kapott a múzeum. A Báthori Zsigmond fejedelem által kiadott, I59I-ben kelt nemesi oklevél adományozója Márk Zoltán sepsiszentgyörgyi lakos. A restaurálását Benedek Éva csíkszeredai restaurátor végezte.

- Újabb Kós Károly-portréval gazdagodott a Gyárfás Jenő Képtár. Kós Károlyt, a 20. századi erdélyi kultúra meghatározó egyéniségét Melocco Miklós Munkácsy- és Kossuth-díjas szobrászmúvész, a mai magyar képzőmúvészet egyik legrangosabb alkotója örökítette meg.

- I833-as székely kapuval bővült a Székely Nemzeti Múzeum gyúitteménye, Futásfalva legrégebbi székely kapuja ez, melyet 20II-ben Tusa Csaba adományozott.

- Gyárfás Jenő: Potsa József főispán arcképe, adományként került a Gyárfás Jenő Képtár gyújteményébe.

- Bortnyik Györoy múvészfotós több ezer negatívjával gazdagodott a Székely Nemzeti Múzeum fotótékája. Az értékes gyújtemény 1969 és 2000 közt készült dokumentumképekből és múvészfotókból áll. A múvvész - aki a hetvenes években a Megyei Tükör címú napilap fényképésze is volt - Háromszék iparosodását, falu- és városképváltozásait, híres embereit, kulturális és politikai eseményeit egyedülállóan dokumentálta. A tulajdonjog átruházásával együtt Bortnyik György a copyright-jogot is a Székely Nemzeti Múzeumra ruházta.

A könyvtár gyarapodása a saját kiadványok gyújtése, vásárlás, adományok és intézményközi csere révén történik. A legnagyobb támogató hagyományosan a Magyar Tudományos Akadémia Könyvtára, a fö partnerek pedig a múzeumi testvérintézmények, a Kriza János Néprajzi Társaság és az Erdélyi Múzeum-Egyesület, a Nemzeti Kisebbségkutató Intézet, a Hargita Megyei Hagyományőrzési Forrásközpont, a Partiumi és Bánsági 
Múemlékvédő és Emlékhely Társaság, az Erdélyi Kárpát-Egyesület, a Debreceni Egyetemi Könyvtár, a Központi Statisztikai Hivatal, a Szépmúvészeti Múzeum, a Brukenthal Múzeum, a kolozsvári Kisebbségkutató Intézet, a Gyulafehérvári Főegyházmegyei Levéltár, a szentendrei Szabadtéri Néprajzi Múzeum, a Magyar Nemzeti Múzeum, a Magyar Természettudományi Múzeum, a Déri Múzeum, a Veszprém Megyei Levéltár voltak; a szerzeményezés elsődlegesen változatlanul a Székelyföldre vonatkozó (siculica) és egyéb romániai magyar honismereti, valamint kisebbségpolitikai szakirodalomra összpontosított.

A természettudományi osztály 20II-ben 42I ormányosbogárral gyarapodott. Preparálásuk, meghatározásuk és számítógépes nyilvántartásba vételük szépen halad.

A régészeti-történelmi osztály az elmúlt évek alatt folytatott régészeti kutatások (ásatások, terepbejárások, helyszíni szemlék) eredményeképpen mintegy 500 tárggyal gazdagodott. A régészeti gyújteményt adományok is bővítették. Konzerválásuk, restaurálásuk, leltári nyilvántartásba vételük jelenleg is folyamatban van. A történelmi gyưjitemény is több, vásárlás vagy adományozás útján beérkezett tárggyal gyarapodott.

A néprajzi osztály az esztendők folyamán 1458 tétellel gyarapodott, jórészt adományok révén. Új szerzeményeink többsége textília és használati tárgy, a fontosabbak közül kiemelnénk - mint különleges tárgyakat - az alsórákosi unitárius egyházközség 19. század eleji szószékkoronáját és úrasztalát, egy nagyenyedi üvegnegatív-hagyatékot, Duka János híres árkosi hangszerkészító egyik korai hegedújét.

A kézdivásárhelyi Incze László Céhtörténeti Múzeum gyújteménye egy év alatt 246 darab adományozott tárggyal gyarapodott, többnyire a viseleti és étkezési szokások tárgykörébe tartozó néprajzi jellegú tárgyak kerültek a múzeumba.

\section{Akkreditálták a sepsiszentgyörgyi Székely Nemzeti Múzeumot}

2012 legfontosabb megvalósítása volt, hogy intézményünk magyar múzeumként Romániában elsőként kapta meg a bukaresti Kulturális Minisztérium által akkreditált múzeumi státust, melyet a Hivatalos Közlönyben megjelent 2289/2012. O6. II-es miniszteri rendelet szentesített. Egy múzeum minisztériumi akkreditálása azt jelenti, hogy magas szinten ellenőrzött és igazolt módon teljesíti mindazokat az eloórásokat és elvárásokat, ame- 

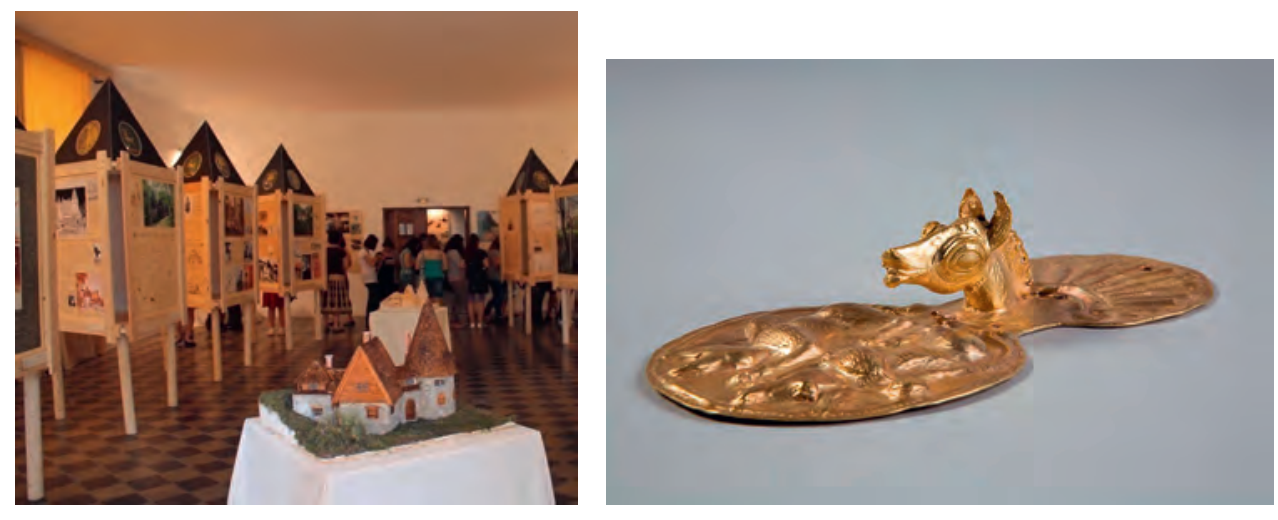

lyeket egy intézménnyel szemben támasztottak: biztosítja a gyúitemények védelmét és állagmegőrzését, bővítését, szakszerú feldolgozását kiállitások és publikációk által, minőségi kulturális szolgáltatásokat nyújt a szakmai-és nagyközönségnek, jövőbe mutató múzeumi menedzsmenttel rendelkezik.

\section{Néprajzi fotótéka honlapunkon}

Több száz néprajzi jellegú fotót tekinthetnek meg látogatóink a Székely Nemzeti Múzeum honlapján (építészet, szokások, mesterségek, mezőgazdaság, állattenyésztés, népviselet, tárgyak, mindennapi élet, életkorok, régészet, helytörténet, Bortnyik-gyújtemény, képzőmúvészet).

A digitalizálási folyamatot a Szülőföld Alap támogatásával valósította meg a múzeum néprajzi részlege.

\section{A Székely Nemzeti Múzeum 2OII-től digitális beléptetőrendszert allkalmaz}

A jegy egyszeri megvétele több sepsiszentgyörgyi helyszín megtekintésére jogosítja fel a vásárlót.

- Pontosabb adatokat kívánunk kapni a kultúrára fogékony közönség látogatási szokásairól, preferenciáiról.

- 2015. június I-től kedvezményes gyújtőjegy lépett érvénybe, mellyel a Székely Nemzeti Múzeum, a Lábas Ház és a Székelyföldi Vadászati Kiállítás látogatható. 


\section{Kós Károly világa, I9I2}

Budapest Fơváros Levéltára és a Székely Nemzeti Múzeum közös vándorkiállítással emlékezett meg a jeles alkotóról, a Kós fiatal építészéveit bemutató tárlat sikeres vándorutat járt be. Kilenc helyszínén, Budapesten, Sepsiszentgyörgyön, Kolozsváron, Kézdivásárhelyen, Csíkszeredában, Udvarhelyen, Gyergyószentmiklóson, Bukarestben, illetve Nagyszebenben közel tízezren voltak kíváncsiak a rendhagyó módon tálalt kiállításra.

20I5-ben a legnagyobb esemény kétségkívül a Románia antik aranyát és ezüstjét bemutató kiállítás volt, amelyre több mint ötezren voltak kíváncsiak.

A Székely Nemzeti Múzeum eddigi történetének valószínúleg legrangosabb, de a benne foglalt tárgyak értékét tekintve mindenképpen a legértékesebb időszakos kiállítását látta vendégül 20I5. július 30-a és szeptember 6-a között.

A Románia Nemzeti Történelmi Múzeumának kezdeményezésével létrejött, a Kulturális Minisztérium által támogatott Románia ókori arany-és ezüstkincsei címú tárlaton eddig soha nem látott mennyiségben és párosításban tekinthettük meg az ország határain belül valaha napvilágot látott leggazdagabb és legértékesebb régészeti emlékek színe-javát.

A kiállításon szereplő összesen Ioo4 tárgy egy része a szervező bukaresti intézmény Történeti Kincstárából származott, míg a többi, mintegy 800 arany- és ezüsttárgyat összesen 3I, a kiállítás létrejöttében együttmúködő vidéki múzeum gyưjiteményéből válogatták össze. A tárlat kiemelkedő gazdagságú leletegyüttesei között láthatók voltak a Székely Nemzeti Múzeum régészeti gyújteményében őrzött, Kr. e. I. századi petőfalvi és szilágysomlyói ezüstkincsek is.

Sokat tanultunk belőle, tesztelhettük az intézmény infrastrukturális és humánerőforrás-kapacitását is. A tárlatot megelőző rendkívüli biztonsági intézkedések, előkészületek és utómunkálatok igen időigenyesek voltak.

Továbbra is fontosnak tartjuk, hogy intézményünk nyisson: ne csak a tudományos eredmények bemutatásában és népszerúsítésében jeleskedjék, hanem a szabadidő szép, kellemes eltöltése irányába is, hogy a látogatónak ne csak az értelmét, hanem a szívét is meg tudjuk szólítani.

Ez irányú erőfeszítéseink szépen kamatozódtak a rendszeresített múzeumpedagógiai programjainkban: a gyerekcsoportok és családosok számára szervezett tematikus napok (gombanap, magyar festészet napja, madarak és fák napja stb.) mellett kiállításainkhoz és rendezvényeinkhez is átfogó múzeumpedagógiai programok kapcsolódtak.

Jelentős érdeklődésnek örvendett az immár negyedik éve megszervezett 
nyári múzeumkerti koncertsorozat, s egyre hangsúlyosabb a Szent Györgynapok városfesztiválban vállalt szerepünk is.

Úgy gondoljuk, hogy aki „civilként” bejön egy kerti rendezvényre, az hamarosan kíváncsivá válik a székházban bemutatott kiállításokra is.

\section{Tudományos élet, díjak, kitüntetések}

Munkatársaink könyv- és levéltári, illetve terepkutatásaik által intenzív tudományos tevékenységet fejtettek ki. Kiállításaik és publikációik által tovább folytatták gyúiteményeink feldolgozását és közkinccsé tételét, emellett folyamatosan rendelkezésére álltak a partnerintézményektől érkező igénylőknek, kutatóknak is.

Osztályainkon a kutatási céllal érkező igénylések száma a százat is meghaladja.

A Bethlen Gábor Alap támogatásával folytat népmúvészeti, népi iparmúvészeti kutatásokat a Székely Nemzeti Múzeum három szakembere.

A Székely Nemzeti Múzeum három kutatója a térség régi temetői kapcsán kutatási alapprogramot indított.

A cél Székelyföld népi és polgári kultúrájának új módszerú és szemléletú feldolgozása. Szőcsné dr. Gazda Enikő három településen a temetőmúvészet történetét vizsgálja. Dr. Kinda István egy 19. századi Kis-Küküllő menti sírkőfaragó család történetét és egyedi munkásságát tárja fel. Dr. Dimény Attila a kézdivásárhelyi társadalom és a régi református temető kapcsolatát kutatja a temetkezési terek elrendezése alapján.

20I4-ben a Magyar Tudományos Akadémia Kolozsvári Területi Bizottsága Fiatal Kutatói Díját társadalomtudományi kategóriában dr. Kinda István muzeológus néprajzkutató, a sepsiszentogyöroyi Székely Nemzeti Múzeum munkatársa vehette át. A Fiatal Kutatói Díj odaítélésében általános szempont maga a tudományos teljesítmény és annak közösségi hatása (legalább olyan értelemben alapkutatások esetében, hogy a hazai képzést, a további kutatásokat erősítse), különös tekintettel az előző egy évben felmutatott teljesítményre.

20I4-ben az Első Nemzetközi Népismereti Filmszemlét Kinda István és Vargyasi Levente filmje nyerte. Az első filmszemlét a dr. Kós Károly Közhasznú Alapítvány szervezésében rendezték Sztánán.

A Magyar Rovartani Társaság a Székely Nemzeti Múzeum természettudós szakemberét, Kocs Irént több évtizedes tudományos kutatómunkája elismeréseként ezüst fokozatú Frivaldszky Imre-emlékplakettel tüntette ki. 
Vinczeffy László sepsiszentogyöroyi képzőmúvészt, restaurátort, a Székely Nemzeti Múzeum szakemberét több évtizedes kiemelkedő képzőmúvészeti tevékenységének elismeréseként Munkácsy Mihály-díjjal tüntették ki.

Szőcsné dr. Gazda Enikő néprajzkutatót, a Székely Nemzeti Múzeum osztályvezető muzeológusát a székelyföldi tárgyi kultúra, népi társadalom és életmód szakszerú kutatásában elért kiváló eredményeiért Bányai János-díjjal tüntették ki.

\section{Kiadványok, katalógusok}

- Acta Siculica 2007, Acta Siculica 2008, Acta Siculica 2009, Acta Siculica 20IO, Acta Siculica 201 I.

- Az Acta Siculica (2013) hatodik kiadása, rendhagyó módon, összevontan két év eredményeit kívánja bemutatni.

- Az Országos Széchényi Könyvtár és a Székely Nemzeti Múzeum közös kiadásában megjelent Pesty Frigyes helynévgyújteménye, I864-I865 - Székelyföld és térsége I-III. kötet.

- Zoltán Székely: Lucrări alese.

- Kinda István (szerk.): A Székely Nemzeti Múzeum. Második, javított és bővített kiadás. (SzNM, 2OI4).

- Kinda István (szerk.): Székely National Museum (SzNM, 20I4).

- Kinda István (szerk.): Muzeul Național Secuiesc (SzNM, 20I4).

- Kinda István: A Csángó Néprajzi Múzeum és gyújteményei (Csángó Néprajzi Múzeum-Kriza János Néprajzi Társaság, 20I4).

- Szőcsné Gazda Enikő: Erdélyi csipkék. Kiállitási katalógus (SzNM, 2OI3).

- Daniel G. Scheint: Az erdélyi székelyek földje és népe természeti, politikai, statisztikai és történelmi szempontból (I833). (SzNM, 2OI2).

- Kós Károly Székely Nemzeti Múzeuma.

- Roediger Lajos: Kászonszék és Háromszék néprajzos szemmel. (Sajtó alá rendezte, bevezető tanulmánnyal ellátta Szőcsné Gazda Enikő) (SzNM, 20I2).

- Csáki Árpád: Pálos misszió Háromszéken a I8. században. (Az illyefalvi rendház és könyvei. ) (SzNM, 20I4).

- Tüdős S. Kinga (szerk.): Kastélyok, udvarházak és lakóik a régi Székelyföldön. In memoriam Demény Lajos (I926-20IO).

- D. Haszmann Orsolya: A csernátoni Haszmann Pál Múzeum.

- Az Erdélyi Múvészeti Központ gyújteményei. 

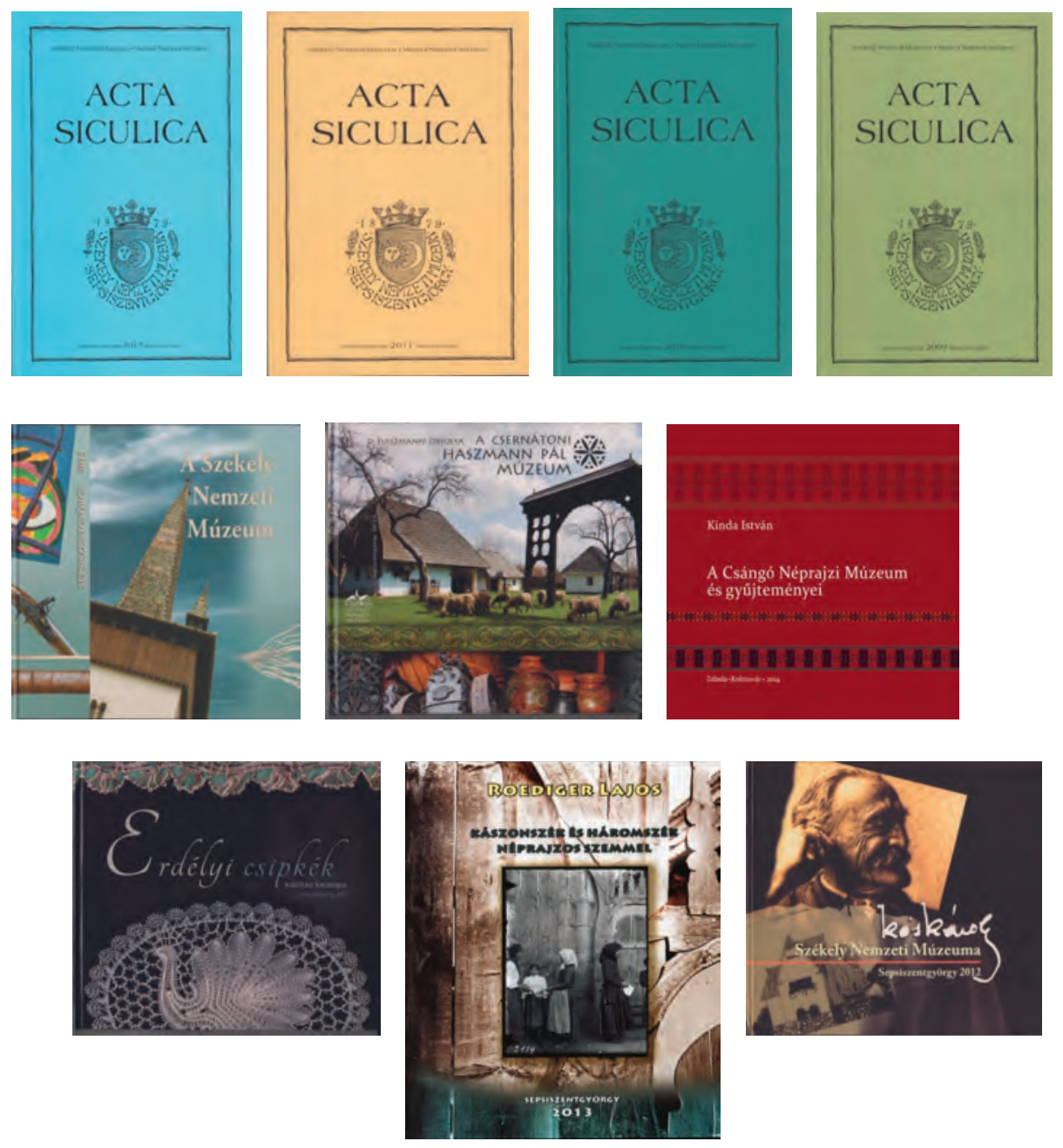

- Vécsi Nagy Zoltán: Szocrelatív - Erdélyi magyar múvészet 1945-1965 között.

- Szőcsné Gazda Enikő: Székelyföldi sgrafitto kerámia;

- Apor-Kódex. I5. század első fele I5. század vége és I520 előtt.

- Jakab Albert Zsolt-Kinda István (szerk.): Aranykapu. Tanulmányok Pozsony Ferenc tiszteletére (Kriza János Néprajzi Társaság - Szabadtéri Néprajzi Múzeum-Székely Nemzeti Múzeum, Kolozsvár, 2015).

Kiemelt támogatónk Magyarország Közigazgatási és Igazságügyi Minisztériuma. 
A Székely Nemzeti Múzeum Alapítvány, illetve a külső egységeink által múkködtetett egyesületek - Magma Kortárs Közeg Egyesület (Sepsiszentgyörgy), Bod Péter Közmúvelődési Egyesület, Haszmann Pál Közmúvelődési Egyesület (Csernáton), Gaál Mózes Közmúvelődési Egyesület (Barót), Kézdivásárhelyi Múzeumbarátok Egyesülete (Kézdivásárhely), Pro Museum Egyesület (Zabola) - pályázati és más források bevonásával jelentős mértékben hozzájárulnak intézményeink fejlesztéséhez, kutatási és könyvkiadói programjaink, valamint múzeumi rendezvényeink költségeinek fedezéséhez.

\section{Gyưijteményi munka}

A könyvtár feldolgozottságát mutatja, hogy elektronikus kiadványkatalógusa az elmúlt időszakban meghaladta a 46 ooo tételt.

A természettudományi osztályon megkezdődött a botanikai gyúijtemény digitalizálása.

A régészet-történelmi osztályon folytatódott a gyúijtemények revíziója és a helyrajzi számozás aktualizálása.

A néprajzi osztály gyarapodása félezernyi tételt jelent, ennek megtörtént a nyilvántartásba vétele.

A fotótéka feldolgozásában közel ötezer az új nyilvántartási tétel, a negatívok és papírképek szkennelési munkálatai nyomán 25 ooo-re emelkedett a digitalizált fotóállomány.

A legfontosabb állagmegőrzési munkálatok között említjük, hogy új szarvazatot és zsindelyezést kapott a szabadtéri részlegen lévő csíki ház, a múzeum udvarán pedig felépült három kopjafatároló.

A Gyárfás Jenő Képtár anyagainak a digitalizálása befejeződött.

A fóépület második emeletén lévő néprajzi alapkiállítás cseréje elkezdődött, ennek munkálatai nyomán a gyújteménykezelők, restaurátorok számos tárgy kiállításra való előkészítését végezték el.

Munkatársaink könyv- és levéltári, illetve terepkutatásaik által intenzív tevékenységet fejtettek ki. Kiállításaik és publikációik által tovább folytatták gyújteményeink feldolgozását és közkinccsé tételét, emellett folyamatosan rendelkezésére álltak a partnerintézményektől érkező igénylőknek, kutatóknak is.

Az elmúlt időszakban erőnk és adottságunk szerint az intézmény belsőkülső megerősítésére, szakmai és látogatói közönségünk jobb, igényesebb szolgálatára fordítottunk. Mi, belső munkatársak egységes szakmai csa- 
pattá próbáltunk válni, azért, hogy hitelesen és eredményesen kovácsoljunk magunk köré értő és érző, törekvéseinkre érzékeny, munkánkra odafigyelő közösséget.

Jóleső érzéssel olvastuk annak a felmérésnek az eredményeit, mely szerint múzeumunk, a színházat követve, a megye második legismertebb kulturális intézménye. Fenntartónk, Kovászna Megye Tanácsának, valamint Sepsiszentgyörgy Polgármesteri Hivatalának támogatása és odafigyelése létfontosságú számunkra, amelyet közösségünk nevében ez alkalommal is köszönünk. 